\title{
SHELTERING BEHAVIOUR OF SPINYCHEEK CRAYFISH (ORCONECTES LIMOSUS) IN THE PRESENCE OF AN ARTIFICIAL MAGNETIC FIELD
}

\author{
A. TAŃSKI (1), K. FORMICKI (1), P. ŚMIETANA (2), M. SADOWSKI (1), A. WINNICKI (1)
}

(1) Agricultural University of Szczecin, Department of Fish Anatomy and Embryology 4 Kazimierza Królewicza St., 71-550 Szczecin, Poland.

(2) University of Szczecin, Department of Ecology, ul. Wąska 13, 71-412 Szczecin, Poland

Reçu le 18 janvier 2005

Received January 18, 2005

Accepté le 6 juin 2005

Accepted June 6, 2005

\begin{abstract}
The potential of artificial hideouts, outfitted with magnets or their imitations (control), to attract spinycheek crayfish Orconectes limosus was studied. The experiments were carried out within 1999-2002 in an 80-hectar natural lake. There were three parallel setups, with three experimental treatments (hideouts) each. The presently acquired results suggest explicitly that the magnetic field generated at the entrance to the hideouts (made of ceramic pipes), affects the movement direction of crayfish. This was evident from statistically significant differences between the numbers of crayfish attracted to the pipes equipped with magnets and to the control ones.
\end{abstract}

Key-words: Spinycheek crayfish, sheltering, artificial magnetic field, magnetoreception.

\section{COMPORTEMENT DE CACHE DE L'ÉCREVISSE AMÉRICAINE (ORCONECTES LIMOSUS) SOUMIS A UN CHAMP MAGNÉTIQUE ARTIFICIEL}

\section{RÉSUMÉ}

L'attractivité de caches artificielles, équipées de sondes magnétiques ou de leurres, a été étudiée chez les écrevisses américaines. Les expériences ont été menées de 1999 à 2000 dans un lac naturel de 80 hectares. Trois lots expérimentaux ont été réalisés avec trois types de traitements (caches). Les résultats suggèrent que le champ magnétique généré à l'entrée des caches (structure en céramique) affecte le sens du déplacement des écrevisses. Il existe des différences significatives sur le nombre d'écrevisses attirées entre des caches équipées de sondes magnétiques et celles des lots témoin.

Mots-clés : écrevisse américaine, cache, champ magnétique artificiel, réception magnétique.

\section{INTRODUCTION}

There have been a number of attempts to identify the orientation mechanisms of aquatic organisms - fish in particular - undertaking longer or shorter migrations. Olfactory 
factors, water currents, activity of stars, or action of the geomagnetic field were listed among the possible clues (GROOT, 1965; WILTSCHKO and WILTSCHKO, 1972; QUINN, 1980; QUINN et al., 1981; ZOGER et al., 1981; QUINN and BRANNON, 1982; QUINN and GROOT, 1983). The geomagnetic field affects the behaviour and a number of metabolic processes of numerous animal species (KIRSCHVINK, 1980; RODDA, 1983, ZOGER et al., 1981). It has also been used for orientation.

Changes of magnetic field can inflict changes in the behaviour and movement direction as well as functional disturbances of organisms invertebrates as hornets (Vespa sp.), fruit flies Drosophila melanogaster(cf. TECHNAN, 1976; BLACHMAN, 1977). In some decapods such as spiny lobster Panulirus argus, certain directional preferences in the N-S (North-South) plain have been demonstrated. The directional reaction of this species followed the imposed changes in the direction of the magnetic field. Such directional reactions of spiny lobsters can be explained by the presence of magnetic substances in their cephalon and abdomen (LOHMANN,1985), and even according to latest research BOLES and LOHMANN, 2003 spiny lobster derives positional information from the Earth's magnetic field. Among arthropods, the above-mentioned phenomenon has been particularly well documented in honey bees (MARTIN and LINDAUER, 1977; COLLETT and BARON, 1994).

There have hitherto been no attempts to study the effect of magnetic field on freshwater crayfish. The studies, done previously in our laboratories, proved that many fish species could orient themselves within magnetic field. Such ability can be used for enhancing the performance of trap fishing gear, commonly used in practice (FORMICKI et al., 2000). The presence of spinycheek crayfish, Orconectes limosus (as a by catch) in our experimental traps and the behaviour of the crayfish during these studies prompted us to investigate the performance of those crustaceans within artificially generated magnetic field (with the background of the geomagnetic field). We were interested how crayfish would react to custom-made hideouts differing in values of artificially generated magnetic field. The designed experimental setup provided a free choice of shelters for the crayfish.

The results of this study, in addition to determining crayfish reactions to constant magnetic field, could have also a practical aspect of enhancing catchability of traps. In the case of spinycheek crayfish this could provide a tool for controlling the expansion rate of this species in Polish waters. Low effectiveness of presently used fishing gear almost completely discouraged fishermen from targeting this species (ŚMIETANA et al., 2004). At present, only the intensive exploitation seems to be the most effective way of reducing the pace of its expansion.

\section{MATERIAL AND METHODS}

This study was carried out within 1999-2002, on the turn of May and June, in an 80hectar Krzemień Lake at the village of Izdeno near Sieraków Wielkopolski. The shoreline of the lake is uniform, covered by aquatic vegetation. The lake is located far from buildings or power lines and its catchment area is predominately wooded. The lake is inhabited by some 20 fish species and the major ones are perch, roach, pike, and most recently also tench and carp. The depth of $36 \mathrm{~m}$ implies its "vendace type", but the extensive eutrophication excluded whitefish and vendace from its ichthyofauna. The lake is connected to the Warta River thorough a narrow stream (flowing out of the lake). There are no tourist centres in the vicinity and the fishing and angling activities are negligible.

Within three years $(1999,2001,2002)$ a number of artificial hideouts for crayfish were placed within the littoral zone. The hideouts consisted of ceramic pipes $1-\mathrm{m}$-long, $7 \mathrm{~cm}$ in diameter, and $1 \mathrm{~cm}$ of wall thickness. The ends of pipes were outfitted with symmetrically 
attached cylindrical magnets (11.6 mm diameter; $4.6 \mathrm{~mm}$ height) (manufactured by Polfer, Warsaw, Poland) or with their rubber imitations (Fig. 1).

Each study involved 3 experimental setups of 3 hideouts (ceramic pipes) each. In each setup, there was one pipe with 8 magnets, one pipe with 4 magnets, and one pipe (control) with rubber magnet imitations (three experimental treatments). To make them look alike, each pipe entrance was outfitted with the same number of units (i.e. the pipe with only 4 magnets had additional 4 magnet imitations while the control had 8 imitations). The $\mathrm{N}$ poles of all magnets were directed offshore. The magnetic field generated within the treatment with 8 magnets in the distance of $10 \mathrm{~cm}$ in the direction perpendicular to the hideout entrance amounted to $0.24 \mathrm{mT}$. In the distance of $1 \mathrm{~cm}$ it assumed value of $0.8 \mathrm{mT}$ (Fig. 2A). In the treatment with 4 magnets, those valued were $0.19 \mathrm{mT}$ and $0.41 \mathrm{mT}$, respectively (Fig. 2B).

The values of the magnetic field were measured with a hallotrone teslameter HTM12 (Institute of Telecommunication and Acoustics, Wrocław Technical University).

The hideouts were deposited in the littoral zone of the lake at the depth of $1 \mathrm{~m}$ with their entrances directed offshore. The distance between setups exceeded 500 meters. The hideouts within each setup were only few meters apart. The number of crayfish in the pipes was monitored daily and the position of hideouts was changed clockwise (Fig. 3). All crayfish caught by pipes were isolated from the lake.

A buoy was attached to each pipe to facilitate their precise placement (Fig. 3). Within the study period each setup was checked 33 times with a total of 297 samples. All captured crayfish were from the same species $O$. limosus.

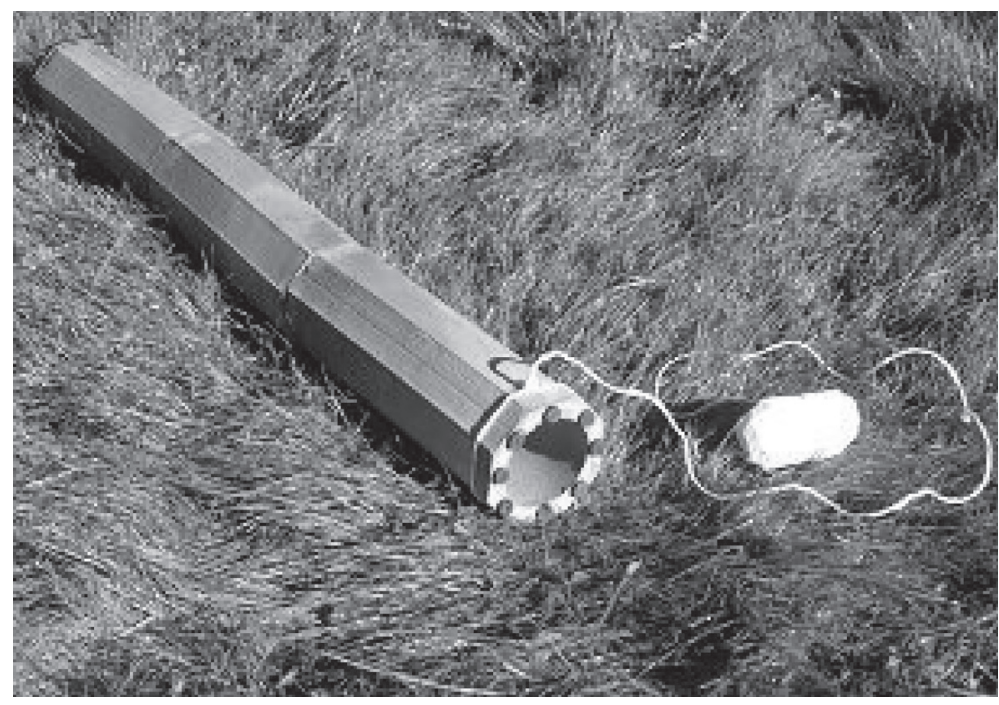

Figure 1

Ceramic hideouts for crayfish with magnets or their imitations attached around their entrance.

Figure 1

Caches en céramique équipées de sondes magnétiques à leurs entrées et caches servant de contrôle. 
A

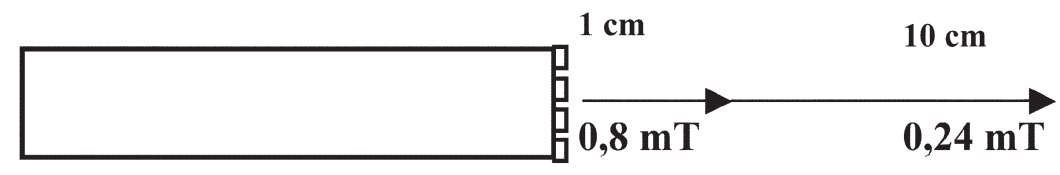

8 magnets

B

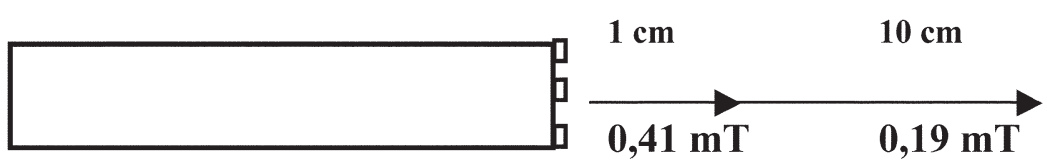

4 magnets

Figure 2

Distribution of the magnetic field values in the treatments with 8 and 4 magnets, respectively.

Figure 2

Distribution des valeurs de champ magnétique dans les expériences avec 8 et 4 sondes.

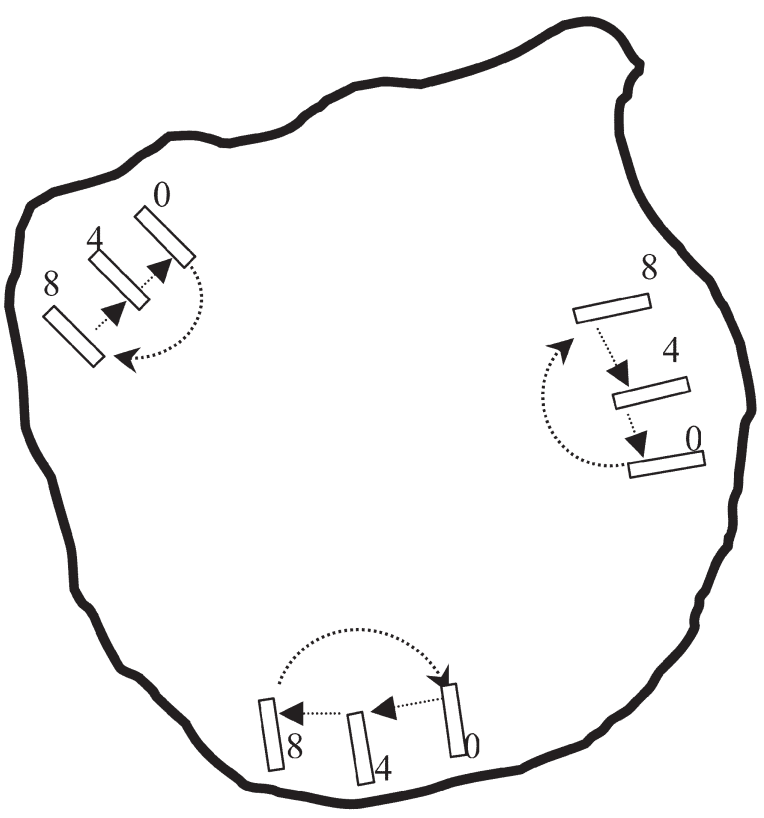

Figure 3

The distribution of the experimental setups and the rotation of the position of pipes in each setup.

Figure 3

Distribution des lots expérimentaux et rotation de la position des tuyaux dans ceux-ci. 


\section{RESULTS}

Statistically significant differences in the numbers of crayfish entering individual pipes were found (Kruskal-Wallis rank test: $H=7.5906$; $P=0.0225$ ) (Fig. 4). It is therefore evident that changes of the magnetic field value, near the hideout entrance affect the process of shelter seeking by spinycheek crayfish. The analysis based on multiple rank tests for all samples (Kruskal-Wallis test) demonstrated a positive effect of the magnetic field generated by magnets on the shelter selection by crayfish. The differences between the control and the experimental treatment with 4 magnets $(0.19 \mathrm{mT}$ at $10 \mathrm{~cm}$;) only marked a tendency described above $(P=0.078)$. In the case, however, of the experimental treatment with 8 magnets $(0.24 \mathrm{mT}$ at $10 \mathrm{~cm})$ the differences in the number of crayfish attracted by pipes were statistically significant $(P=0.045)$, compared to the treatment without magnets (control).

It can be therefore concluded that magnetic field can affect the hideout selection by spinycheek crayfish and the increased values of the field were distinctly more attractive for this crustacean.

\section{DISCUSSION}

There is no evidence that spinycheek crayfish my have a magnetic material in their organisms but assuming the analogy to its presence in lobsters (LOHMANN, 1985) we may

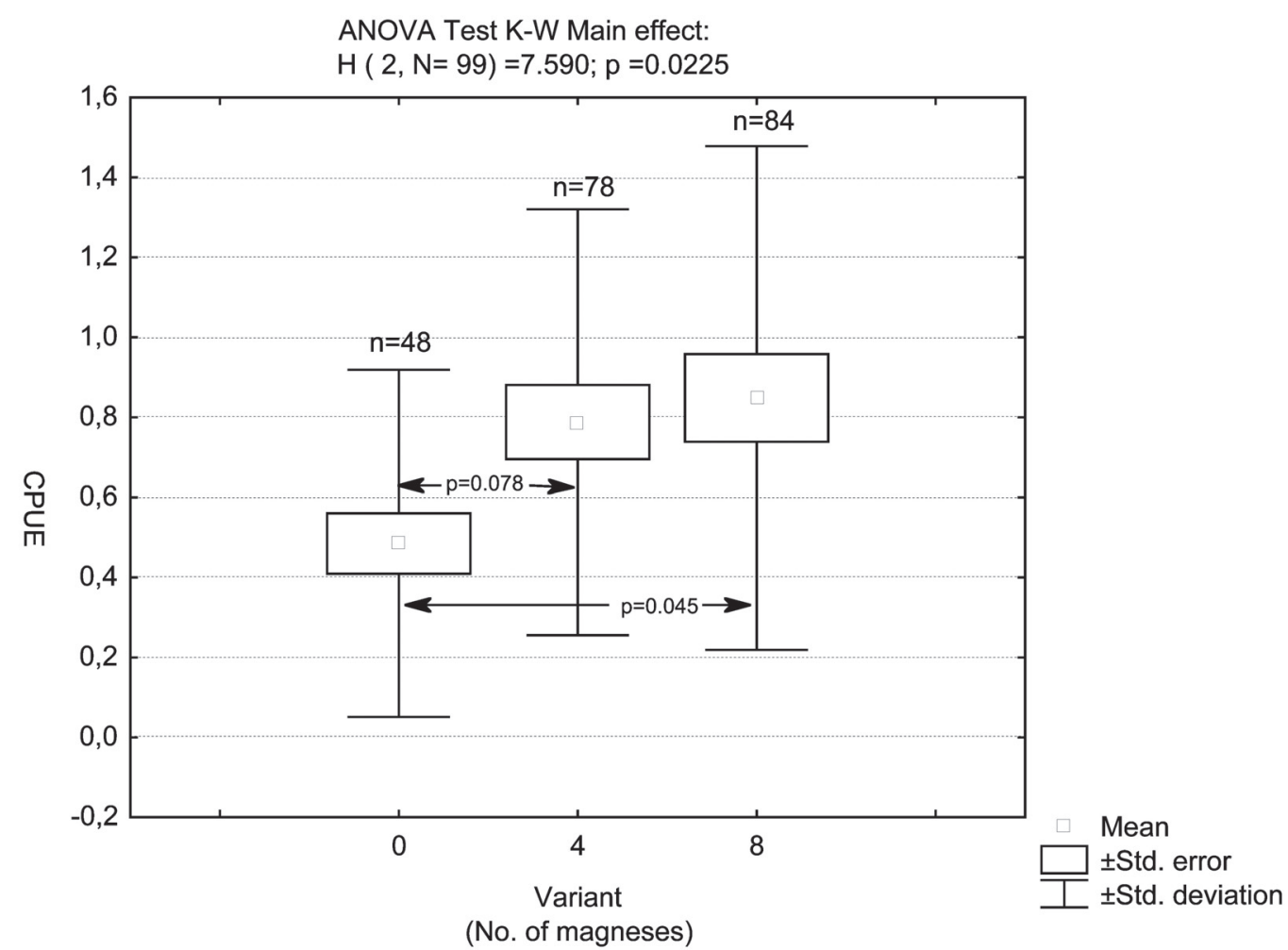

Figure 4

The number of spinycheek crayfish attracted by hideouts in individual experimental treatments $(n=210)$.

Figure 4

Nombre d'écrevisses américaines entrant dans les caches lors des différentes expériences $(n=210)$. 
conclude that this factor could be a clue to the ability of crayfish to react to the changes in the magnitude of magnetic field which is exemplified by their behaviour in the proximity of the field source.

The presently acquired results provide explicit evidence that the magnetic field generated at the entrances of the hideouts, made of ceramic pipes, affected the movement direction of crayfish.

Gradient changes of magnetic field can affect defined organism reactions and at the same time change its movement direction as it has been demonstrated for adult fish caught with fyke-nets outfitted with permanent magnets (FORMICKI et al., 2004b). As has been mentioned earlier, reactions of organisms in constant, natural and artificially generated magnetic field are an outcome of action of those fields to entire organism, or probably on its magnetic material.

The presence of the magnetic material has been detected, for example, in denticle capping of chitons Acanthopleura echinatum, A. spiniger, Chiton tuberculatus (LOWENSTAM, 1967; RATNER, 1976), in the cephalosome of spiny lobsters Panulirus argus (LOHMANN, 1985). No data is available on possible presence of magnetic material in crayfish (spinycheek crayfish in particular). Apparently this crustacean has not been studied in such aspect.

During our experiments, the crayfish randomly moving in the littoral zone of the lake had a choice of entering the pipe, going the other direction or hiding underneath. The entering of a crayfish in the zone of artificially generated magnetic field probably caused their anxiety and triggered so called "exploration reflex". The above assumption has been formulated by FORMICKI et al. (2000, 2004a) who obtained similar results, while studying effect of stationary magnets on fishes caught by fykenet - a trap fishing gear. A directional reaction of aquatic invertebrates to the geomagnetic field has been hitherto observed only in spiny lobster, Palinurus argus (BOLES and LOHMANN, 2003). Also a magnetic material was found in the cephalothorax of the same species and its presence is probably associated with magnetoreception (LOHMANN, 1985). No data is available, however, on the magnetic sensitivity of this crustacean (BOLES and LOHMANN, 2003).

It seems that the magnetic field generated by magnets, distributed around the hideout entrance, increased interest in the pipe in crayfish affected by it. The higher magnitude of the constant field (treatment with 8 magnets), and at the same time wide range of its action, resulted in even stronger reaction of the crayfish and their active movement towards the interior of the hideout.

Because a similar behavioural pattern, as the one described above, was earlier observed in fish (FORMICKI et al., 2004b), this phenomenon was presently used as the reference system for the interpretation of the results obtained for crayfish. A need for further, detailed studies on this issue must be emphasized, however.

The presently acquired results demonstrated a sensitivity of spinycheek crayfish to changes in the value of the magnetic field. Also a directional reaction was observed. Although our studies were not focused on the use of the geomagnetic field to magnetic orientation of spinycheek crayfish (as has been observed by BOLES and LOHMANN, 2003), we may conclude that the observed magnetic sensitivity may support such assumption.

\section{REFERENCES}

BLACHMAN N.M., 1977, Electronics and hornet's nest meet at Tel Aviv University. European Scientific Notes ONR, 178-180.

BOLES L.C., LOHMANN K.J., 2003. True navigation and magnetic maps in spiny lobsters. Nature, 421, 60-63. 
COLLETT T.S., BARON J., 1994. Biological compasses and the coordinate frame of landmark memories in honeybees. Nature, 368, 137-140.

FORMICKI K., SADOWSKI M., TAŃSKI A., KORZELECKA-ORKISZ A., WINNICKI A., 2004a. Behaviour of trout (Salmo trutta L.) larvae and fry in a constant magnetic field. Journal of Applied Ichthyology. Berlin, 20, 290-294.

FORMICKI K., TAŃSKI A., SADOWSKI M., WINNICKI A., 2004b. Effects of magnetic field on fyke net performance. Journal of Applied Ichthyology. Berlin, 20, 402-406.

FORMICKI K., TAŃSKI A., WINNICKI A., 2000. Preliminary results of studies on magnetic field effects on semi-circular fyke net catch potential. Fol. Univ. Agric. Stetin., 214 Piscaria (27), 69-74.

GROOT C., 1965, On the orientation of young sockeye salmon (Oncorhynchus nerka) during their seaward migration out of lakes. Behav. Suppl., 14, 1-198.

KIRSCHVINK J.L., 1980. South-seeking magnetic bacteria. J. Exp. Biol., 86, 345-347.

LOHMANN K.J., 1985. Geomagnetic field detection by the western Atlantic spiny lobster, Panulirus argus. Mar. Behav. Physiol., 12, 1-17.

LOWENSTAM H.A., 1967. Lepidocrite, an apatite mineral, and magnetite in teeth of chitons (Polyplacophora). Science, 156, 1373-1375.

MARTIN H., LINDAUER M., 1977. Der Einfluss des Erdmagnetfeldes auf die Schwereorientierung der Honigbiene (Apis mellifica). J. Comp. Physiol., 122, 145187.

QUINN T.P., 1980. Evidence of celestial and magnetic compass orientation in lake migrating sockeye salmon fry. J. Comp. Physiol., 137A, 243-248.

QUINN T.P., BRANNON E.L., 1982. The use of celestial and magnetic cues by orienting sockeye salmon smolts. J. Comp. Physiol., 147, 547-552.

QUINN T.P., GROOT C., 1983: Orientation of chum salmon (Oncorhynchus keta) after internal and external magnetic field alteration. Can. J. Fish. Aquat. Sci., 40, 15981606.

QUINN T.P., MERRIK R.T., BRANNON E.L., 1981. Magnetic field detection in sockeye salmon. J. exp. Zool., 217, 137-142.

RATNER S.C., 1976. Kinetic movements in magnetic fields of chitons with ferromagnetic structures. Behav. Biol., 17, 573-578.

RODDA G.H., 1983. Homeward paths of displaced juvenile alligators as determined by radiotelemetry. Behav. Ecol. Sociobiol., 14, 241 - 246.

ŚMIETANA P., KRZYWOSZ T., STRUŻYŃSKI W., 2004. Review of National Restocking Program "Active Protection of Native Crayfish in Poland" 1999-2001. Bull. Fr. Pêche Piscic., 372-373, 289-301.

TECHNAN G, 1976. Der Einfluss der Erdmagnetfeldes auf Entwicklung von Drosophila melanogaster. Zulassungsarbeit Univ. Würzburg.

WILTSCHKO W., WILTSCHKO R., 1972. Magnetic compass of European robins. Science, $176,62-64$.

ZOGER J., DUNN J.R., FULLER M., 1981. Magnetic material in the head of the common Pacific dolphin. Science, N.Y., 213, 892-894. 
